\title{
Study on the prevalence and neonatal lethality in patients with selected congenital anomalies as per the data of the National Registry of Congenital Anomalies of Argentina
}

\author{
María Paz Bidondo, M.D. ${ }^{a}$, Boris Groisman, M.D. ${ }^{a}$, Juan A. Gilia, B.S..${ }^{a, b}$, \\ Rosa Liascovich, M.D. ${ }^{a}$, and Pablo Barbero, M.D. ${ }^{a}$ \\ Collaborators: Verónica Pingray, Magister, and members of the RENAC Task Force \\ (see Annex)
}

a. National Registry

of Congenital

Anomalies

(Registro Nacional de Anomalías

Congénitas,

RENAC), National

Center for Genetic

Medicine (Centro

Nacional de

Genética Médica,

CNGM), National

Administration

of Labs and

Health Institutes

(Administración

Nacional de

Laboratorios e

Institutos de Salud, ANLIS).

b. Latin-American

Collaborative

Study of Congenital

Malformations

(Estudio

Colaborativo

Latinoamericano

de Malformaciones

Congénitas,

ECLAMC - CEMIC)

E-mail Address: María Paz Bidondo, M.D.: mariapazbidondo@ gmail.com

\section{Funding:}

The study was partially funded by the Comisión Nacional

Salud Investiga,

through a Carrillo-

Oñativia scholarship

for 2012, and the Plan

Nacer, Ministry of

Health.

Conflict of Interest:

None.

Received: 12-2-2014

Accepted: 3-12-2015

\begin{abstract}
Introduction. Congenital anomalies (CAs) account for $26 \%$ of infant mortality in Argentina. The lethality rate for CAs measures the risk of death among affected infants.

Objectives. To describe the prevalence at birth of a group of selected CAs, to estimate the neonatal lethality rate, and to examine its association with different variables.

Population and Methods. The study was conducted using data provided by the National Registry of Congenital Anomalies. Prevalences of encephalocele, spina bifida, gastroschisis, omphalocele, diaphragmatic hernia, esophageal atresia, intestinalatresia, or anorectalmalformation were estimated (2009-2013 period). Lethality was assessed at 7 and 28 days of life in affected infants with an isolated anomaly (2013). Association with the following variables was analyzed: sex, gestationalage, birth weight, antenatal ultrasound screening, percentage of unmet basic needs in the district where the mother lives, geographic region, and level of care at the hospital where the delivery took place.

Results. Gastroschisis was themost prevalentCA (8.53/10,000births), while diaphragmatic hernia was the CA with the highest neonatal lethality rate $(66.67 \%)$. Out of all selected CAs, there was a significant association between an higher gestational age and survival at 7 days -OR: 0.81 (0.70-0.95)-and survival at 28 days-OR: 0.79 (95\% confidence interval [CI]: 0.68-0.91)-. A higher percentage of unmet basic needs was associated with a higher lethality for diaphragmatic hernia -OR: 1.59 (95\% CI: 1.30-1.95)- and for intestinal atresia or anorectal malformation -OR: 16.00 (95\% CI: 1.63-157.24)-.

Conclusions. Thehigh prevalence of gastroschisis is consistent with the increase observed globally. Prematurity and a high percentage of unmet basic needs increased the risk of death among affected infants.
\end{abstract}

Keywords. neonatal mortality, congenital anomalies, lethality, infant mortality, Argentina.

http:/ / dx.doi.org/10.5546/aap.2015.eng.295

\section{INTRODUCTION}

In the past decades in Argentina, the epidemiological transition ${ }^{1}$ has led to a reduction in infant mortality (IM) and its two components: neonatal mortality (before 28 days of life) and postneonatal mortality (between 28 days of life and one year old). As of the 1970s, the relative importance of neonatal mortality has increased and exceeded the postneonatal component. In 2012, there were 8227 infant deaths in Argentina, with an infant mortality rate of 11.1 per 1000 live births. Most deaths took place in the neonatal period, which accounted for $67 \%$ of all deaths. ${ }^{2}$

In this setting, the relative importance of congenital anomalies (CAs), which correspond to Chapter XVII (qoo-qqq) of the International Classification of Diseases, has risen. At present, CAs are the second cause of IM, but are more relevant as a cause of death than prematurity and low birth weight related disorders.

CAs account for $26 \%$ of infant mortality, ${ }^{2}$ with deaths predominantly occurring in the neonatal period. ${ }^{4}$ However, the relative importance of CAs in infant mortality is geographically heterogeneous and largely depends on the management of other causes of death across the different jurisdictions. ${ }^{4}$

The risk of death among newborn infants with CAs depends on different factors, such as the severity of each specific anomaly, the clinical characteristics of patients, and the opportunity to access medical/surgical care. This study focuses on a group of selected CAs: encephalocele, spina bifida, gastroschisis, omphalocele, diaphragmatic hernia, esophageal 
atresia/stenosis with or without fistula, intestinal atresia/stenosis, and anorectal malformations. These CAs were selected based on their impact on morbidity and mortality, their prevalence, and because they can be reduced through medical/ surgical interventions. To date, there are no publications on the topic of neonatal lethality rate among infants affected with CAs in Argentina.

The objectives of this study were to describe the prevalence at birth of selected CAs, to estimate the neonatal and early neonatal lethality rates among newborn infants with such isolated CAs, and to examine their association with different variables at the maternity centers participating in the National Registry of Congenital Anomalies (RENAC) so as to identify determining factors that may be the subject of future interventions.

\section{POPULATION AND METHODS}

The target population of this study was all infants born at the hospitals participating in the RENAC, whose coverage reached $65 \%$ of births in the public sector and 38\% of all births in Argentina in 2013. The RENAC was started in 2009 in four hospitals and progressively included the most important maternity centers of Argentina. In 2013, there were 122 participating institutions from the public sector. The RENAC is made up of a network of neonatologists who collect data from the hospitals and a coordinating body. Neonatologists record all live births and stillbirths with a weight of $>500$ grams who have CAs at birth, describe anomalies present, and complete other variables as per procedures standardized in an operational manual and an atlas. In each hospital, there are at least two RENAC representatives responsible for submitting data. The coordinating body reviews the quality of descriptions made and has geneticists code CAs, then reviews and shares the information in regular reports. ${ }^{5}$

The RENAC's organization and operation have been previously published. ${ }^{6}$

This study consisted of two stages: prevalence and lethality. The first stage included all live births and stillbirths with a weight of $>500 \mathrm{~g}$ who had any of the selected CAs as detected by the RENAC between November 1st 2009 and December $31^{\text {st }}, 2013$. Cases were classified into live births or stillbirths and into isolated CAs, multiple CAs, or syndromic cases. Cases of isolated CAs are defined as those with a major single $C A$, or two or more major CAs corresponding to a sequence or located in the same body structure. Cases of multiple CAs are defined as those with major CAs affecting different, unrelated body structures and corresponding to a known (association) or unknown pattern. Syndromic cases are defined as those with a definite cause.

The prevalence of selected CA was estimated as per Poisson's distribution, with a $95 \%$ confidence interval. For each selected CA, estimations included the percentage of live births and stillbirths, and of cases with isolated CAs, cases with multiple CAs, and syndromic cases.

The second stage, the lethality study, included follow-up until one month old of infants born between January $1^{\text {st }}$ and December $31^{\text {st }}, 2013$ who had an isolated selected CA. Lethality analysis was conducted using data only from 2013, since the number of maternity centers included by that year was considered adequate.

The early neonatal lethality rate (ENLR; death before 7 days of life) and the overall neonatal lethality rate (ONLR; death before 28 days of life) were estimated. These rates were stated as percentages and estimated as the ratio between the number of live newborn infants affected by each CA and those deceased in each period (numerator) over the total number of live newborn infants affected by each CA (denominator).

In order to investigate factors involved in ENLR and ONLR, their association with the following variables was analyzed. Sex: female/male. Gestational age (GA): analyzed as a continuous variable. Birth weight (weight): analyzed as a continuous variable. Antenatal ultrasound screening: yes/no; defined as no screening if the Division of Neonatology lacked antenatal data on CAs either because no ultrasound had been performed or because there were no pathological findings. Level of care at the hospital where the delivery took place (category IIIB versus IIIA + II as per the National Ministry of Health's classification). ${ }^{7}$ Geographic region of the hospital where the delivery took place: Patagonia, Center, Cuyo, Northwest (NOA), and Northeast (NEA). Percentage of population with unmet basic needs $(\% \mathrm{UBNs})^{8}$ in the district where the mother lives: analyzed as a continuous variable. Data on weight were obtained in $98.4 \%$ of cases; on gestational age, in $98.8 \%$; on sex, in $98.8 \%$; on antenatal diagnosis, in $100 \%$; on the hospital level of care, in $96.6 \%$; and on $\%$ UBNs, in $98.7 \%$.

First of all, associations were analyzed by grouping all newborn infants with selected CAs. As a measure of association, the adjusted risk (OR) was estimated for each variable using a multivariate logistic regression analysis. Secondly, 
each CA was analyzed and its association was assessed using a bivariate analysis to estimate the risk (OR). For the assessment of the association between the hospital level of care and antenatal diagnosis, an adjusted ${ }^{2}$ test was performed using the Mantel-Haenszel test to estimate the $p$ value stratified by type of malformation and considering a statistical significance level of 0.05 (type I error= $5 \%)$. The statistical software used was Stata 11.1.

\section{RESULTS}

There were 2275 cases with selected CAs out of a total of 703,325 births assessed between November $1^{\text {st }}, 2009$ and December $31^{\text {st }}, 2013$. Of these cases, $95.64 \%$ were live births and $4.31 \%$ were stillbirths; $66.24 \%$ of cases had isolated CAs, $26.29 \%$ had multiple CAs, and $7.47 \%$ were syndromic cases. The most prevalent CA was gastroschisis (Table 1).

For the lethality study, there were 528 live newborn infants born between January $1^{\text {st }}$ and December 31 $31^{\text {st }}, 2013$ who had an isolated CA. Survival up to 7 days of life was reported in $471 / 528(89.20 \%)$, while follow-up continued up to 28 days of life in $436 / 528$ (82.58\%). Diaphragmatic hernia was the anomaly with the highest ENLR (57.38\%) and ONLR (66.67\%); spina bifida was the anomaly with the lowest ONLR $(2.50 \%)$ and was not associated with any death before 7 days of life; values for the remaining CAs were intermediate (Table 2).
In terms of studied variables, the following results were observed for the total of 528 infants affected with isolated CAs: $394 / 510(77.25 \%)$ were born at hospitals with a IIIB level of care; male sex ratio was $1.10(276 / 251)$; mean weight was 2667.10 grams $(\mathrm{SD}=678.40)$; mean gestational age was 36.90 weeks $(\mathrm{SD}=2.43)$; mean \%UBNs was $10.71 \%$; and 308/528 (58.33\%) had an antenatal diagnosis. The percentage of antenatal screening for each anomaly was as follows: $88.89 \%$ for encephalocele, $74.02 \%$ for gastroschisis, $68.57 \%$ for spina bifida, $62.50 \%$ for omphalocele, $65.4 \%$ for diaphragmatic hernia, $25.6 \%$ for esophageal atresias, $23.33 \%$ for intestinal atresias and anorectal malformations. At hospitals with a IIIB level of care, $65.52 \%$ of cases had had an antenatal diagnosis, while at hospitals with a II or IIIA level of care, only $34.48 \%$ of cases had been diagnosed antenatally.

A statistically significant association was observed between antenatal screening and the level of care at the hospital where the delivery took place $\left(\chi^{2}=26.59 ; p \leq 0.001\right)$, which was stratified into the seven CA categories.

In the review of all newborn infants with selected CAs, a statistically significant association was observed between survival of affected infants and their gestational age, both in the early neonatal period (adjusted OR: 0.81; 95\% $\mathrm{CI}=0.70-0.95)$ and in the overall neonatal period (adjusted OR: 0.79; 95\% CI= 0.68-0.91). Likewise, the increase of the \%UBNs in the district where

TABLE 1. Prevalence at birth of selected congenital anomalies and distribution by outcome and clinical presentation. National Registry of Congenital Anomalies, Argentina, 2009-2013

\begin{tabular}{|c|c|c|c|c|c|c|c|c|c|c|c|c|c|}
\hline \multirow[t]{3}{*}{ Congenital anomaly } & \multirow[t]{3}{*}{ Cases } & \multirow[t]{3}{*}{$\begin{array}{c}\text { Prevalence } \\
\times 10,000(95 \% \text { CI })^{*}\end{array}$} & \multicolumn{5}{|c|}{ Cases by outcome } & \multicolumn{6}{|c|}{$\begin{array}{c}\text { Cases by } \\
\text { clinical presentation }\end{array}$} \\
\hline & & & \multicolumn{2}{|c|}{ Live births } & \multicolumn{2}{|c|}{ Stillbirths } & \multirow[t]{2}{*}{ NS } & \multicolumn{2}{|c|}{ Isolated } & \multicolumn{2}{|c|}{ Multiple } & \multicolumn{2}{|c|}{ Syndromic } \\
\hline & & & $\mathrm{n}$ & $\%$ & $\mathbf{n}$ & $\%$ & & $\mathbf{n}$ & $\%$ & $\mathbf{n}$ & $\%$ & $\mathbf{n}$ & $\%$ \\
\hline Gastroschisis & 600 & $8.53(7.86-9.24)$ & 573 & 95.50 & 27 & 4.50 & 0 & 546 & 91.00 & 52 & 8.67 & 2 & 0.33 \\
\hline Spina bifida & 389 & $5.53(4.99-6.11)$ & 372 & 95.87 & 16 & 4.12 & 1 & 305 & 78.41 & 72 & 18.51 & 12 & 3.08 \\
\hline Anorectal malformation & 231 & $3.28(2.87-3.74)$ & 218 & 94.37 & 13 & 5.63 & 0 & 116 & 50.22 & 112 & 48.48 & 3 & 1.30 \\
\hline Esophageal atresia & 230 & $3.27(2.86-3.72)$ & 227 & 98.70 & 3 & 1.30 & 0 & 98 & 42.61 & 117 & 50.87 & 15 & 6.52 \\
\hline Diaphragmatic hernia & 225 & $3.20(2.79-3.65)$ & 219 & 97.33 & 6 & 2.67 & 0 & 164 & 72.89 & 54 & 24.00 & 7 & 3.11 \\
\hline $\begin{array}{l}\text { Intestinal atresia } \\
\text { (jejunum-ileum) }\end{array}$ & 218 & $3.10(2.70-3.54)$ & 217 & 99.54 & 1 & 0.46 & 0 & 110 & 50.46 & 32 & 14.68 & 76 & 34.86 \\
\hline Omphalocele & 167 & $2.37(2.03-2.76)$ & 144 & 86.23 & 23 & 13.77 & 0 & 64 & 38.32 & 93 & 55.69 & 10 & 5.99 \\
\hline Duodenal atresia & 118 & $1.68(1.39-2.01)$ & 117 & 99.15 & 1 & 0.85 & 0 & 53 & 44.92 & 24 & 20.34 & 41 & 34.75 \\
\hline Encephalocele & 97 & $1.38(1.12-1.68)$ & 89 & 91.75 & 8 & 8.25 & 0 & 51 & 52.58 & 42 & 43.30 & 4 & 4.12 \\
\hline Total & 2275 & & 2176 & 95.64 & 98 & 4.31 & & 1507 & 66.24 & 598 & 26.29 & 170 & 7.47 \\
\hline
\end{tabular}

NS: not specified; CI: confidence interval.

* Prevalence estimated on 703,325 births out of the total number of cases (live births and stillbirths). 
the mother lives showed a tendency towards increasing the risk of death in both periods, although it was not statistically significant. The antenatal screening variable was excluded because it was collinear with the hospital level of care variable (Table 3 ).

The highest percentage of deceased infants in the neonatal period was observed in the Northwest (NOA); however, differences among regions were not statistically significant $(p=0.147)$ (Table 4). The percentage of births covered by the public subsector in all regions was over $50 \%$.

In the review of each separate CA, omphalocele and encephalocele were excluded because the number of cases was insufficient. It was not possible to estimate adjusted risks because of the number of deceased infants with each CA.

A statistically significant association was observed between a shorter survival and an increased \%UBNs for diaphragmatic hernia and intestinal and anorectal atresia. Likewise, a risk over 5 was observed in relation to low birth weight and preterm birth for esophageal atresia and spina bifida, although these results were not statistically significant (Table 5).

\section{DISCUSSION}

This was the first study conducted in Argentina with the purpose of determining the prevalence and lethality of selected CAs based on data with a high coverage from across the 24 jurisdictions in the country. Both the prevalences observed and the proportion of isolated, multiple and syndromic cases by CA category are consistent with the values expected as per the international bibliography. However, it is worth noting that the frequency of gastroschisis was high. The frequency of this congenital anomaly has been increasing worldwide. ${ }^{9}$ This situation has been strongly associated with younger maternal ages and, to a lesser extent, with other factors such

TABLE 2. Newborn infants with isolated selected congenital anomalies: percentage of follow-up and deceased before 7 and 28 days of life. National Registry of Congenital Anomalies, Argentina, 2013

\begin{tabular}{lccccc}
\hline CA & $\begin{array}{c}\text { Total number } \\
\text { of affected } \\
\text { infants }\end{array}$ & $\begin{array}{c}\text { Follow-up } \\
\text { until 7 days } \\
\text { of life }\end{array}$ & $\begin{array}{c}\text { Follow-up } \\
\text { until 28 days } \\
\text { of life }\end{array}$ & $\begin{array}{c}\text { Deceased before } \\
\text { 7 days of life } \\
\text { (ENLR) }\end{array}$ & $\begin{array}{c}\text { Deceased before } \\
\text { 28 days of life } \\
\text { (ONLR) }\end{array}$ \\
\hline Gastroschisis & 204 & $186 / 204(91.18 \%)$ & $173 / 204(84.80 \%)$ & $10 / 186(5.38 \%)$ & $18 / 173(10.40 \%)$ \\
Spina bifida & 105 & $92 / 105(87.62 \%)$ & $80 / 105(76.19 \%)$ & $0 / 92(0.00 \%)$ & $2 / 80(2.50 \%)$ \\
Intestinal atresia and ARM & 90 & $78 / 90(86.67 \%)$ & $72 / 90(80.00 \%)$ & $1 / 78(1.28 \%)$ & $3 / 72(4.17 \%)$ \\
Diaphragmatic hernia & 65 & $61 / 65(93.85 \%)$ & $60 / 65(92.31 \%)$ & $35 / 61(57.38 \%)$ & $40 / 60(66.67 \%)$ \\
Esophageal atresia & 39 & $32 / 39(82.05 \%)$ & $32 / 39(82.05 \%)$ & $4 / 32(12.50 \%)$ & $8 / 32(25.0 \%)$ \\
Omphalocele & 16 & $14 / 16(87.50 \%)$ & $13 / 16(81.25 \%)$ & $3 / 14(21.43 \%)$ & $6 / 13(46.15 \%)$ \\
Encephalocele & 9 & $8 / 9(88.89 \%)$ & $6 / 9(66.67 \%)$ & $1 / 8(12.50 \%)$ & $2 / 6(33.33 \%)$ \\
Total & 528 & $471 / 528(89.20 \%)$ & $436 / 528(82.58 \%)$ & $54 / 471(11.46 \%)$ & $79 / 436(18.12 \%)$ \\
\hline
\end{tabular}

CA: congenital anomaly; ENLR: early neonatal lethality rate; ONLR: overall neonatal lethality rate;

ARM: anorectal malformation.

TABLE 3. Risk of death in the early neonatal and overall neonatal periods in newborn infants with selected anomalies, as per the different variables. National Registry of Congenital Anomalies, Argentina, 2013

\begin{tabular}{lcc}
\hline Variables & $\begin{array}{c}\text { Before 7 days } \\
\text { of life OR (95\% CI) }\end{array}$ & $\begin{array}{c}\text { Death } \\
\text { of life OR (95\% CI) }\end{array}$ \\
\hline < Birth weight* & $1.00(0.99-1.00)$ & $1.00(0.99-1.00)$ \\
$>$ Gestational age* & $0.81(0.70-0.95)$ & $0.79(0.68-0.91)$ \\
Female sex & $0.55(0.30-1.02)$ & $0.60(0.35-1.01)$ \\
$>\%$ UBNs in the district where the mother lives & $1.05(1.00-1.10)$ & $1.05(1.00-1.10)$ \\
Low level of care at the hospital where & & $0.58(0.29-1.20)$ \\
the delivery took place & $0.77(0.36-1.68)$ &
\end{tabular}

\%UBNs: percentage of unmet basic needs; OR: odds ratio; CI: confidence interval.

* Variables continuously reviewed. 
as: urogenital infections in the periconceptional period, low body mass index, low socioeconomic level, and tobacco, alcohol and illegal drug use. ${ }^{9-11}$

The antenatal ultrasound detection rate observed in the cases of encephalocele, spina bifida, gastroschisis, diaphragmatic hernia, and omphalocele was lower than that described in other studies. ${ }^{12,13}$ Intestinal and esophageal atresias were the CAs with the lowest detection rate, quite likely because ultrasound findings are indirect. ${ }^{14,15}$

During the follow-up of affected infants, it was possible to recover over $80 \%$ of cases. Diaphragmatic hernia was the CA with the highest lethality rate, and most deaths occurred in the early neonatal period. This is classified as a "hardly reducible" anomaly as per the criteria of the National Ministry of Health,; ${ }^{16}$ therefore, findings observed in this study are consistent with such classification. The high lethality rate of diaphragmatic hernia may be the reason for the higher percentage of deceased infants in the NOA region.

Spina bifida was the only CA associated with no deaths before 7 days of life and with a lower ONLR, which is consistent with follow-up studies that have reported most deaths occurred after one year old..$^{17,18}$

TABLE 4. Number of deceased cases with isolated selected congenital anomalies and overall neonatal lethality rate (ONLR) by geographic region of the hospital where the delivery took place. National Registry of Congenital Anomalies, Argentina, 2013

\begin{tabular}{|c|c|c|c|c|c|c|c|c|c|}
\hline Region Ga & $\begin{array}{r}\text { roschisis } \\
\text { an } \\
\mathrm{m}\end{array}$ & $\begin{array}{l}\text { Spina } \\
\text { bifida } \\
\text { and anorectal } \\
\text { nalformation }\end{array}$ & $\begin{array}{l}\text { Diaphragmatic } \\
\text { atresia } \\
\end{array}$ & $\begin{array}{c}\text { Intestinal } \\
\text { hernia }\end{array}$ & $\begin{array}{c}\text { Esophageal } \\
\text { atresia }\end{array}$ & Omphalocele & Encephalocele & $\begin{array}{l}\mathrm{N} \text { deceasec } \\
\mathrm{N} \text { affected }\end{array}$ & $\begin{array}{l}d / \text { ONLR } \\
\text { d }(95 \% \mathrm{CI})\end{array}$ \\
\hline Patagonia & 0 & 0 & 0 & 2 & 0 & 0 & 0 & $2 / 26$ & $\begin{array}{c}7.69 \% \\
(0.93-27.80) \\
\end{array}$ \\
\hline Center & 11 & 1 & 0 & 19 & 4 & 6 & 2 & $43 / 249$ & $\begin{array}{c}17.27 \% \\
(12.50-23.27)\end{array}$ \\
\hline Cuyo & 0 & 0 & 0 & 5 & 0 & 0 & 0 & $5 / 33$ & $\begin{array}{c}15.15 \% \\
(5.00-35.36)\end{array}$ \\
\hline NOA & 3 & 1 & 3 & 12 & 3 & 0 & 0 & $22 / 80$ & $\begin{array}{c}27.50 \% \\
(17.23-41.64)\end{array}$ \\
\hline NEA & 4 & 0 & 0 & 2 & 1 & 0 & 0 & $7 / 48$ & $\begin{array}{c}14.58 \% \\
(5.86-30.05)\end{array}$ \\
\hline Total & 18 & 2 & 3 & 40 & 8 & 6 & 2 & $79 / 436$ & $\begin{array}{c}18.12 \% \\
(14.35-22.58)\end{array}$ \\
\hline
\end{tabular}

Region: Patagonia (Chubut, La Pampa, Neuquén, Río Negro, Santa Cruz, Tierra del Fuego); Center (Autonomous City of Buenos Aires, Buenos Aires, Córdoba, Entre Ríos, Santa Fe); Cuyo (La Rioja, Mendoza, San Juan and San Luis); NOA (Catamarca, Jujuy, Salta, Santiago del Estero and Tucumán); NEA (Corrientes, Chaco, Formosa and Misiones).

CI: confidence interval.

TABLE 5. Risk of death before 28 days of life in newborn infants with selected anomalies examined separately, as per the different variables. National Registry of Congenital Anomalies, Argentina, 2013

\begin{tabular}{|c|c|c|c|c|c|}
\hline \multirow[t]{2}{*}{ Variables } & \multicolumn{5}{|c|}{ Isolated anomalies OR (95\% CI) } \\
\hline & $\begin{array}{l}\text { Diaphragmatic } \\
\text { hernia }\end{array}$ & $\begin{array}{l}\text { Esophageal } \\
\text { atresia }\end{array}$ & Gastroschisis & $\begin{array}{l}\text { Spina } \\
\text { bifida }\end{array}$ & $\begin{array}{c}\text { Intestinal atresia } \\
\text { and anorectal } \\
\text { malformation }\end{array}$ \\
\hline$<$ Birth weight* & $1.05(0.70-1.60)$ & $5.44(0.76-39.25)$ & $1.56(0.54-4.51)$ & $5.58(0.37-83.32)$ & 0.00 \\
\hline$>$ Gestational age* & $0.95(0.61-1.48)$ & $5.44(0.76-39.25)$ & $1.72(0.68-4.37)$ & $6.18(0.42-91.77)$ & 0.00 \\
\hline Female sex & 0.77 (0.51-1.17) & $0.95(0.28-3.27)$ & $1.06(0.44-2.54)$ & $1.05(0.07-16.23)$ & $\begin{array}{c}2.65 \\
(0.25-26.87)\end{array}$ \\
\hline $\begin{array}{l}>\% \text { UBNs in the district } \\
\text { where the mother lives }\end{array}$ & $1.59(1.30-1.95)$ & $1.80(0.50-6.51)$ & $1.45(0.46-4.58)$ & 0.00 & $\begin{array}{c}16.00 \\
(1.63-157.24)\end{array}$ \\
\hline $\begin{array}{l}\text { Low level of care at the } \\
\text { hospital where the delivery } \\
\text { took place }\end{array}$ & $0.86(0.53-1.38)$ & $0.41(0.06-2.84)$ & $0.38(0.05-2.72)$ & $2.55(0.17-38.93)$ & $1.69(0.16-17.43)$ \\
\hline
\end{tabular}

\%UBNs: percentage of unmet basic needs; OR: odds ratio; CI: confidence interval.

* Variables continuously reviewed. 
Neonatal lethality rates in the cases of intestinal atresia and anorectal atresia observed in our study are similar to those reported in other studies. ${ }^{19}$ Neonatal lethality for gastroschisis, omphalocele and esophageal atresia observed in other investigations was generally below the rates observed in our study. ${ }^{20-22}$ Consistent with our work, several studies have associated prematurity to a higher mortality rate among infants affected with selected CAs. ${ }^{18,20,23-25}$ However, some investigations conducted in gastroschisis patients have demonstrated that elective preterm C-sections prevented the occurrence of intestinal inflammation and improved enteral functioning because the exposure time of bowel loops to amniotic fluid meconium was shorter. ${ }^{26,27}$ The results of other studies are not consistent with this latter observation. ${ }^{28,29}$

In our study, results showed a tendency that correlated shorter survival with a lower birth weight when specifically examining esophageal atresia and myelomeningocele; however, this association was not statistically significant. As per the bibliography, low birth weight is a risk factor for the survival of newborn infants with CAs. ${ }^{18,20,25,30}$ In the case of esophageal atresia, the patient's weight is a criterion internationally established as a mortality prognostic factor when conducting pre-surgical assessments. ${ }^{31}$

Regarding the review of unfavorable socioeconomic indicators and CAs, Pawluk, et al. ${ }^{32}$ found an association between poverty (as measured by family and regional socioeconomic level indices) and the prevalence at birth of ventricular septal defect (VSD) and oral clefts. On their side, Vrijheid, et al. observed a positive association between a low maternal socioeconomic level and newborn infants with non-chromosomal septal heart defects and gastrointestinal anomalies. ${ }^{33}$ Bronberg, et al. found no association between the mortality rate of a specific CA and the socioeconomic disadvantage of the districts where mothers live. ${ }^{4,34}$ In our study, an increased \%UBNs showed a significant association with the risk of death, specifically in cases of diaphragmatic hernia and intestinal/ anorectal atresias. Such result may indicate that the most disadvantaged districts are the ones with greater difficulties in having access to perinatal care. Consistent with our findings, Smith, et al. observed a higher risk of death in newborn infants with isolated CAs whose mothers lived in financial hardship. ${ }^{35}$

The estimated lethality rates may serve as an indicator to assess the impact of health interventions and as an input to organize antenatal or immediate neonatal referral services for newborn infants with CAs. The Ministry of Health has recently established the Tertiary Care Perinatal Package, which is one of the priority items for the implementation of the SUMAR Program as of 2013. This set of services includes the CAs analyzed in this study and is considered important since it has been selected for its potential to have a significant impact on the reduction of the hard core of infant mortality.

A strength of this study is that it included newborn infants from the main public maternity centers across the 24 jurisdictions of Argentina, with a high birth coverage.

One of its weaknesses is the number of affected newborn infants lost to follow-up. Another limitation is that, in the analysis of each separate CA, it was not possible to estimate the adjusted risk of each CA in both periods because of the small sample size. In addition, it is not possible to rule out the effect of the socalled ecological fallacy for the \%UBNs variable since there are no individual data available on maternal socioeconomic level. Finally, although the coverage of births in each region was over $50 \%$, this coverage was heterogeneous.

\section{CONCLUSION}

Prevalences of studied CAs were consistent with expected values. Gastroschisis was the most prevalent CA, while diaphragmatic hernia was the CA with the highest lethality rate. Prematurity and socioeconomic hardship variables increased the risk of death among affected infants.

\section{REFERENCES}

1. Frenk J, Frejka T, Bobadilla JL, Stern C, et al. La transición epidemiológica en América Latina. Bol Oficina Sanit Panam 1991;111(6):485-96.

2. Ministerio de Salud de la Nación Argentina. Dirección de Estadísticas e Información de Salud. Estadísticas vitales. Información básica - Año 2012. Buenos Aires, 2013. [Accessed on: March 1, 2014]. Available at: http:/ / www. deis.gov.ar/publicaciones/archivos/Serie5Nro56.pdf.

3. The Royal College of Paediatrics and Child Health Classification - Paediatric Adaptation of ICD-10. European Surveillance of Congenital Anomalies. 2008. [Accessed on: March 16, 2015]. Available at: http://www.eurocatnetwork.eu/content/EUROCAT-Q-Chapter-2008.pdf.

4. Bronberg R, Alfaro E, Chaves E, Dipierri J. Mortalidad infantil por malformaciones congénitas en Argentina: análisis del quinquenio 2002-2006. Arch Argent Pediatr 2009;107(3):203-11.

5. Registro Nacional de Anomalías Congénitas de Argentina. Reporte anual RENAC 2014. Análisis epidemiológico de las anomalías congénitas en recién nacidos registradas en el año 2013 en la República Argentina. Buenos Aires: Ministerio Salud de la Nación, 2014. 
6. Groisman B, Bidondo MP, Barbero P, GiliJA, et al. RENAC: Registro Nacional de Anomalías Congénitas de Argentina. Arch Argent Pediatr 2013;111(6):484-94.

7. Resolución 306/2002. Norma de organización y funcionamiento de los servicios de Neonatología y Cuidados Intensivos Neonatales. Ministerio de Salud de la Nación. Ciudad de Buenos Aires, Argentina, 23 de mayo de 2002.

8. Instituto Nacional de Estadísticas y Censos. Base de datos del INDEC, Censo Nacional de Población, Hogares y Viviendas 2010, procesado con Redatam+SP. Resultados básicos hogares al menos un indicador NBI. Buenos Aires, 2014. [Accessed on: April 2, 2014]. Available at: http:/ /200.51.91.245/argbin/RpWebEngine.exe/Portal Action?\&MODE=MAIN\&BASE=CPV2010B\&MAIN=We bServerMain.inl.

9. Castilla EE, Mastroiacovo P, Orioli IM. Gastroschisis: international epidemiology and public health perspectives. Am J Med Genet C Semin Med Genet 2008;148C(3):162-79.

10. Feldkamp ML, Reefhuis J, Kucik J, Krikov S, et al. Casecontrol study of self-reported genitourinary infections and risk of gastroschisis: findings from the national birth defects prevention study, 1997-2003. BMJ 2008;336(7658):1420-3.

11. Rasmussen SA, Frías JL. Non-genetic risk factors for gastroschisis. Am J Med Genet C Semin Med Genet 2008;148C(3):199-212.

12. Boyd PA, Rounding C, Kurinczuk JJ. Third Report of the Congenital Anomaly Register for Oxfordshire, Berkshire and Buckinghamshire(CAROBB) Births 2005-2010. Oxford: National Perinatal Epidemiology Unit, 2012.

13. Campaña H, Ermini M, Aiello HA, Krupitzki H, et al. Prenatal sonographic detection of birth defect in 18 hospitals from South America. J Ultrasound Med 2010;29(2):203-12.

14. Calisti A, Olivieri C, Coletta R, Briganti V, et al. Jejunoileal atresia: factors affecting the outcome and long term sequelae. J Clin Neonatol 2012;1(1):38-41.

15. Houben $\mathrm{CH}$, Curry JI. Current status of antenatal diagnosis, operative management and outcome of esophageal atresia/ tracheo-esophageal fistula. Prenat Diagn 2008;28(7):667-75.

16. Argentina. Ministerio de Salud de la Nación, Sociedad Argentina de Pediatría. Mortalidad Infantil según Criterios de Reducibilidad. Tercera revisión. Sistema Estadístico de Salud. Serie 3. Número 56. Buenos Aires, 2014. [Accessed on: January 20, 2015]. Available at: http://www.msal. gov.ar/images/stories/bes/graficos/0000000193cnt-s03criterios-reducibilidad.pdf.

17. Oakeshott $P$, Hunt GM. Long-term outcome in open spina bífida. Br J Gen Pract 2003;53(493):632-6.

18. Bol KA, Collins JS, Kirby RS. Survival of infants with neural tube defects in the presence of folic acid fortification. Pediatrics 2006;117(3):803-13.

19. Dalla Vecchia LK, Grosfeld JL, West KW, Rescorla FJ, et al. Intestinal atresia and stenosis: a 25-year experience with 277 cases. Arch Surg 1998;133(5):490-6.

20. Clark RH, Walker MW, Gauderer MW. Factors associated with mortality in neonates with gastroschisis. Eur J Pediatr Surg 2011;21(1):21-4.

21. Deng K, Qiu J, Dai L, Yi L, et al. Perinatal mortality in pregnancies with omphalocele: data from the Chinese national birth defects monitoring network, 1996-2006. BMC Pediatr 2014;14:160.

22. Alshehri A, Lo A, Baird R. An analysis of early nonmortality outcome prediction in esophageal atresia. J Pediatr Surg 2012;47(5):881-4

23. García HJ, Aparicio de la Luz S, Franco-Gutiérrez M, González-Lara D, et al. Factores pronósticos asociados a mortalidad en recién nacidos con hernia diafragmática congénita. Gac Med Mex 2003;139(1):7-14.

24. Tsao K, Allison ND, Harting MT, Lally PA, et al.Congenital diaphragmatic hernia in the preterm infant. Surgery 2010;148(2):404-10.

25. Nembhard WN, Salemi JL, Ethen MK, Fixler DE, et al. Mortality among infants with birth defects: Joint effects of size at birth, gestational age, and maternal race/ethnicity. Birth Defects Res A Clin Mol Teratol 2010;88(9):728-36.

26. Hadidi A, Subotic U, Goeppl M, Waag KL. Early elective cesarean delivery before 36 weeks vs late spontaneous delivery in infants with gastroschisis. J Pediatr Surg 2008;43(7):1342-6.

27. Glasmeyer P, Grande C, Margarit J, Martí M, et al. Gastrosquisis. Cesárea electiva pretérmino y cierre primario inmediato; nuestra experiencia. Cir Pediatr 2012;25(1):12-5.

28. Carnaghan H, Pereira S, James CP, Charlesworth PB, et al. Is early delivery beneficial in gastroschisis? J Pediatr Surg 2014;49(6):928-33.

29. Maramreddy H, Fisher J, Slim M, Lagamma EF, et al. Delivery of gastroschisis patients before 37 weeks of gestation is associated with increased morbidities. J Pediatr Surg 2009;44(7):1360-6.

30. Adams-Chapman I, Hansen NI, Shankaran S, Bell EF, et al. Ten-year review of major birth defects in VLBW infants. Pediatrics 2013;132(1):49-61.

31. Okamoto T, Takamizawa S, Arai H, Bitoh Y, et al. Esophageal atresia: prognostic classification revisited. Surgery 2009;145(6):675-81.

32. Pawluk MS, Campaña H, Gili JA, Comas B, et al. Determinantes sociales adversos y riesgo para anomalías congénitas seleccionadas. Arch Argent Pediatr 2014; 112(3): 215-23.

33. Vrijheid M, Dolk H, Stone D, Abramsky L, et al. Socioeconomic inequalities in risk of congenital anomaly. Arch Dis Child 2000; 82(5):349-52.

34. Bronberg RA, Gutiérrez Redomero E, Alonso MC, Dipierri JE. Mortalidad infantil por malformaciones congénitas y condición socioeconómica: el caso de la Argentina. Rev Panam Salud Pública 2012; 31(6):469-75.

35. Smith LK, Budd JL, Field DJ, Draper ES. Socioeconomic inequalities in outcome of pregnancy and neonatal mortality associated with congenital anomalies: population based study. BMJ 2011; 343:d4306. 


\section{ANNEX}

\section{BUENOS AIRES}

Hospital Abraham Piñeyro, Junín: Sonia Moretta, M.D., Jorge Herce, M.D.

Hospital Ana Goitía, Avellaneda: Adriana Mosquera, M.D., Valeria Vera, M.D.

Hospital Alende, Lomas de Zamora: Adrián Toffe, M.D., Ana Carolina Rocco, M.D.

Hospital Argentina Diego, Azul: Victoria Rizzo, M.D.

Hospital Bocalandro, Tres de Febrero: Mariana Oreglia, M.D., David Fernández, M.D.

Hospital Carlos Gianantonio, San Isidro: Blanca Cristina Senra, M.D., María Laura Sznitowsky, M.D.

Hospital Diego Thompson, San Martín: Alicia Fana, M.D., Lidia Santana, M.D.

Hospital Equiza, González Catán: Rubén Goncalvez, M.D., Rodolfo Zaiat, M.D.

Hospital Eurnekian, Ezeiza: José Vega Chancafe, M.D.

Hospital Eva Duarte de Perón (formerly Menem), Malvinas Argentinas: Elisa Duro, M.D.

Hospital Eva Perón, San Martín: Maricel Pontorno, M.D., Andrea Becerra, M.D.

Hospital Evita, Lanús: Marta Noemí Raggio, M.D., Graciela Schabvlosky, M.D.

Hospital Evita Pueblo, Berazategui: Mercedes Córdoba, M.D., FabiánTomasoni, M.D.

Hospital Fiorito, Avellaneda: Felicitas Fumiere, M.D.

Hospital Gandulfo, Lomas de Zamora: Juan Carlos Delucca, M.D., Laura Botti, M.D.,

Viviana Cosentino, M.D.

Hospital Héroes de Malvinas, Merlo: Patricia Wittbecker, M.D.

Hospital Iriarte, Quilmes: Graciela Carballido, M.D.

Hospital Larcade, San Miguel: Beatriz Velázquez, M.D., Fabiana Olivera, M.D.

Hospital Lucio Meléndez, Adrogué: Ana Barsellini, M.D., Ana Carolina Rocco, M.D.

Hospital M. V. Martínez, Pacheco: Stella Maris Benítez, M.D.

Hospital Mariano y Luciano de la Vega, Moreno: Adriana Dagostino, M.D., Sabrina Chattah, M.D.

Hospital Maternidad Santa Rosa, Vicente López: Carina Tula, M.D., Patricia Moreno, M.D.

Hospital Meissner, Pilar: Stella Maris Benítez, M.D., Natalia González, M.D.

Hospital Mercante, José C. Paz: Gabriela Klinge, M.D., Julieta Sada, M.D.

Hospital Mi Pueblo, Florencio Varela: Cecilia Iraira, M.D., María José Wernisch, M.D.

Hospital Narciso López, Lanús Este: Mónica Jewtuszyk, M.D., Viviana Pagani, M.D.

Hospital O. B. de Lavignolle, Morón: Teresa Gentile, M.D., Verónica Figueredo, M.D.

Hospital Oller, San Francisco Solano: Melvin Barrantes, M.D.

Hospital P. V. Cordero, San Fernando: Marcelo Prieto, M.D., María Marta Sánchez Vera, M.D.

Hospital Paroissien, La Matanza: Andrea Puss Barraza, M.D., Magdalena Bisbal, M.D.

Hospital Penna, Bahía Blanca: María Fernanda Maurín, M.D., Sonia Scardapane, M.D.

Hospital Nacional Alejandro Posadas, Haedo: Verónica Pingray, M.D., Isabel Micelli, M.D.,

Alicia Aranaz, B.S.

Hospital Presidente Perón, Avellaneda: Mariana Brautigam, M.D.

Hospital San Felipe, San Nicolás: Graciela Olloco, M.D.

Hospital San José, Pergamino: Ángela Pacífico, M.D.

Hospital San Martín, La Plata: Graciela Ramos, M.D., Marcos Miró, M.D.

Hospital San Martín, La Plata: Noemí Orellano, B.S., Ana Ceccon, M.D., María Rosa Toncich, M.D.

Hospital Tetamanti, Mar del Plata: Eduardo Gil, M.D., Jorge Raverta, M.D.

Hospital Virgen del Carmen, Zárate: Carlos Bachiochi, M.D.

Hospital Emilia Ferreyra, Necochea: Liliana Espelet, M.D.

Hospital Dr. Ramón Santamarina, Tandil: Miguel Barrichelo, M.D.

\section{AUTONOMOUS CITY OF BUENOS AIRES}

Hospital Álvarez: M. Luisa Celadilla, M.D., Adriana Israilev, M.D.

Hospital Argerich: Ana Tocci, M.D., Karenith Santome, M.D.

Hospital Durand: Julio Falk, M.D., Noemí Nakayama, M.D.

Hospital Fernández: Ernesto Goldschmidt, M.D., Mrs. Paula Molina.

Hospital Maternidad Sardá: Graciela Fernández, M.D., Mrs. M. Carmen Arbones.

Hospital Penna: Elena Cristiano, M.D. 
Hospital Piñero: Mariana Panzitta, M.D., Gabriela Hernández, M.D., Claudia Epelbaun, M.D.

Hospital Pirovano: Alberto Capriata, M.D.

Hospital Ramos Mejía: Rubén Bronberg, M.D.

Hospital Rivadavia: Luis Somaruga, M.D., Alcira Oliva, M.D.

Hospital Santojani: Daniela Rottenberg, M.D., Valeria Castellano, M.D.

Hospital Vélez Sársfield: Mario Mardyks, M.D.

Hospital de Clínicas José de San Martín: Estela Enriquez, M.D.

\section{CATAMARCA}

Maternidad 25 de Mayo: Inés Camacho, M.D., Marcos Toledo, B.S.

\section{CÓRDOBA}

Hospital Maternidad Nacional, Córdoba: Yanina Dalsasso, M.D., Marcela del Valle Ogas, M.D.

Hospital Maternidad Provincial, Córdoba: Cynthia Sánchez Topic, M.D.,

Susana del Valle Ramaciotti, M.D.

Hospital Materno Neonatal, Córdoba: Raquel Lucía Torres, M.D., Marcela Beatriz Quaglia, M.D.

Hospital Misericordia, Córdoba: Andrea Paola Chirino Misissian, M.D., Débora Gurevich, M.D.

Hospital Pasteur, Villa María: Patricia Calvo, M.D.

Hospital Maternidad Kowalk, Río Cuarto: Diana Portela, M.D., Paola Pía Allende, M.D.

Hospital Río Cuarto, Río Cuarto: María Laura Bonora, M.D., Nydia Berguío, M.D.

\section{CORRIENTES}

Hospital J. Vidal, Corrientes: María del Rosario Córdoba, M.D., Elsa Aguirre, B.S.

Hospital Ángela Iglesias del Llano: Laura Palacios, M.D.

\section{CHACO}

Hospital J. Perrando, Resistencia: Dina Juárez de Ribles, M.D., Andrea Lew, M.D.

Hospital 4 de Junio, Pres. Roque Sáenz Peña: Ana Lucía Domínguez, M.D.

Hospital Güemes, Castelli: Rosana Medina, M.D.

\section{CHUBUT}

Hospital Andrés Isola, Pto. Madryn: María Soledad Silva, M.D., Norma Inés Segundo, B.S.

Hospital Centro Materno Infantil Trelew, Trelew: Raúl Musante, M.D.

Hospital Regional de Comodoro Rivadavia, Comodoro Rivadavia:

Maximiliano Medina Alarcón, M.D.

Hospital Zonal de Esquel, Esquel: Martín Batisttesa, M.D.

\section{ENTRE RÍOS}

Hospital Centenario, Gualeguaychú: Margarita Otaegui, M.D., Néstor Gieco, M.D.

Hospital Urquiza, Concepción del Uruguay: Adriana Gasparini, M.D., Adriana Reinoso, M.D.

Hospital Masvernat, Concordia: María Cecilia Arizabalo, M.D.

Hospital San Roque, Paraná: Mariel Bordenave, B.S.

\section{FORMOSA}

Hospital Madre y Niño, Formosa: Carina González, M.D., Marinela Antinori, M.D.

\section{JUJUY}

Hospital Guillermo Patterson, San Pedro: Mercedes Grau Toral, M.D.

Hospital Jorge Uro, La Quiaca: Nora Tolaba, M.D.

Hospital Orias, Libertador General San Martín: Alejandro Moragas, M.D.

Hospital Pablo Soria, San Salvador de Jujuy: Julia Flores, M.D., Claudia Carlos, M.D.,

Sonia Alavar, M.D. 


\section{LA PAMPA}

Hospital Establecimiento Asistencial Gobernador Centeno, General Pico: Alejandro Irrazábal, M.D. Hospital Lucio Molas, Santa Rosa: SilvinaRe, M.D.

\section{LA RIOJA}

Hospital de la Madre y el Niño (formerly Vera Barros), La Rioja: Soledad Carrizo del Moral, M.D., Susana Beatriz Garello, M.D.

\section{MENDOZA}

Hospital Lagomaggiore, Mendoza: Cristina de Gaetano, M.D., Gabriela Torres, M.D.

Hospital Paroissien, Maipú: Claudia Beatriz Pizarro. M.D.

Hospital Perrupato, San Martín: Sonia Vilma Shiratori, M.D.

Hospital Scaravelli, Tunuyán: Gustavo Fernández, M.D.

Hospital Schestakow, San Rafael: Oscar Prieto, M.D.

\section{MISIONES}

Hospital El Dorado, El Dorado: Evelyn Heliana Spengler, M.D.

Hospital de Oberá, Oberá: Nelly Vaccari, M.D.

Hospital Ramón Madariaga, Posadas: Maris Carlucci, M.D., Bety Dedieu, M.D.,

Mónica Kosteki, M.D.

\section{NEUQUÉN}

Hospital Castro Rendón, Neuquén, Neuquén: María Eugenia Ponce Zaldúa, M.D.,

Silvia Avila, M.D.

Hospital Heller, Neuquén: Silvia Avila, M.D., Luciana Fernández de Bon, M.D.

\section{RÍO NEGRO}

Hospital de General Roca, General Roca: Daniela Leimbgruber, M.D.

Hospital Ramón Carrillo, Bariloche: María Fabiana Tenreyro, M.D.

\section{SALTA}

Hospital Público Materno Infantil (formerly Hospital El Milagro), Salta: Mariela Vilte, M.D., María Dolores Ruiz, M.D.

Hospital San Vicente Paul, San Ramón de la Nueva Orán: Alexandra Villareal, M.D.,

Franz Ancalle Michell, M.D.

Hospital Juan Domingo Perón, Tartagal: Beatriz Escalante, M.D.

\section{SAN JUAN}

Hospital Rawson, San Juan: Alejandra Sanz, M.D., Mirta Armesto, B.S., Silvia Mateos, M.D., Claudia Manrique, M.D.

\section{SAN LUIS}

Hospital Complejo Sanitario San Luis, San Luis: Laura Espinosa, M.D.

Hospital Juan Domingo Perón, Villa Mercedes: Jesús Ibáñez, M.D.

\section{SANTA CRUZ}

Hospital Regional de Río Gallegos, Río Gallegos: Alicia Susana Guanuco, M.D.

\section{SANTA FE}

Hospital Jaime Ferre, Rafaela: Miriam Estela Martínez, M.D.

Hospital Maternidad Martin, Rosario: Hilda Beatriz Fernández, M.D.

Hospital Provincial de Rosario, Rosario: Verónica Willimburgh, M.D.

Hospital Roque Sáenz Peña, Rosario: Griselda Arrastia, M.D., Gladis Terre, M.D.

Hospital del Centenario, Rosario: Verónica Inés Cicao, M.D., Alejandro Rossi, M.D.

Hospital Eva Perón, Rosario: Fernando Basualdo, M.D., Natalia Vázquez Parachú, M.D. 
Hospital Iturraspe, Santa Fe: Norma Domínguez, M.D.

Hospital J. M. Cullen, Santa Fe: Laura Peralta, M.D.

Hospital Alejandro Gutiérrez, VenadoTuerto: Leonardo Andrés Fedre, M.D.

\section{SANTIAGO DEL ESTERO}

Hospital Ramón Carrillo, Santiago del Estero: Lidia Esther Padilla de Álvarez, M.D., Claudia Jugo, M.D., Mónica Morelli, M.D.

\section{TIERRA DEL FUEGO}

Hospital de Río Grande, Río Grande: Eduardo Zunino, M.D., Alejandra Albanesi, M.D.

Hospital de Ushuaia, Ushuaia: Sergio Nicolussi, M.D.

\section{TUCUMÁN}

Hospital Belascuain, Concepción: Lorena González Arias, M.D.

Hospital Maternidad Nuestra Señora de las Mercedes, S. M. de Tucumán: César Saleme, M.D.

Hospital Nicolás Avellaneda, S. M. de Tucumán: Claudia Montenegro, M.D. 